Article

\title{
The Role of the Motility of Methylobacterium in Bacterial Interactions in Drinking Water
}

\author{
Erifyli Tsagkari *(i) and William T. Sloan
}

School of Engineering, College of Science and Engineering, University of Glasgow, Glasgow G12 8LT, UK; William.Sloan@glasgow.ac.uk

* Correspondence: Erifyli.Tsagkari@glasgow.ac.uk; Tel.: +44-783-363-7863

Received: 14 September 2018; Accepted: 30 September 2018; Published: 3 October 2018

check for updates

\begin{abstract}
Bacterial motility is one important factor that affects biofilm formation. In drinking water there are key bacteria in aggregation, whose biology acts to enhance the formation of biofilms. However, it is unclear whether the motility of these key bacteria is an important factor for the interactions between bacteria in drinking water, and, subsequently, in the formation of aggregates, which are precursors to biofilms. Thus, the role of the motility of one of these key bacteria, the Methylobacterium strain DSM 18358, was investigated in the interactions between bacteria in drinking water. The motility of pure Methylobacterium colonies was initially explored; if it was affected by the viscosity of substrate, the temperature, the available energy and the type of substrate. Furthermore, the role of Methylobacterium in the interactions between mixed drinking water bacteria was investigated under the mostly favourable conditions for the motility of Methylobacterium identified before. Overall, the motility of Methylobacterium was found to play a key role in the communication and interactions between bacteria in drinking water. Understanding the role of the motility of key bacteria in drinking water might be useful for the water industry as a potential tool to control the formation of biofilms in drinking water pipes.
\end{abstract}

Keywords: colonies; drinking water; Methylobacterium; motility

\section{Introduction}

Bacterial motility is one important factor that affects the adhesion of bacteria to a surface. Bacterial adhesion is the first stage for the formation of biofilms on an available substrate. Bacterial appendages, such as flagella, fimbriae, and pili, are found to function as bridges between cells and surfaces and might contribute so that bacteria attach irreversibly to the surfaces. These cell appendages are closely related to the cell motility [1,2]. On the other hand, detachment is the last stage of biofilm growth, and it is caused by local instabilities within the physical biofilm structure in combination with external forces. Again, cell motility is an important factor that affects bacterial detachment. Cell detachment from a surface can be achieved by different types of cell motility [3-5]. Thus, bacterial motility plays a key role in biofilm growth as it enables bacteria to overcome the electrostatic forces between them and the surfaces they colonise. In drinking water, in particular, under low flow conditions, cell motility is important for the transport of bacteria from the bulk water to the exposed surfaces [6-8].

Bacterial motility is found to regulate the production of genes that control the expression of virulence determinants. These determinants enable bacteria to invade host cells [9-12], and, thus, it is critical in the aggregation of bacteria, where microorganisms interact with each other, forming a cluster that is free-floating and can be attached to a substratum as part-of or a precursor-to a biofilm [13-16]. The role of cell motility in bacterial aggregation is important, especially where no external physical forces are pushing the bacteria together [17]. Chemotaxis, which describes certain movements of bacteria towards favourable conditions due to chemicals existing in their surrounding 
environment [18,19], is important for the regulation and control of the direction of cell movement and the extent of bacterial colonisation, as it plays a significant role in the nutrient consumption and cycling in the surrounding environment $[17,19]$. In addition, quorum sensing, which describes the cell-to-cell communication using chemical molecules [20], has been shown to coordinate the motility of bacteria and trigger specific behavioural responses in a bacterial population that presumably benefit the bacteria in a particular environment [21-23].

One of the conditions affecting bacterial motility is the moisture of the substrate. Thus, the viscosity of the substrate has been often tested for affecting bacterial motility, and different agar concentrations have been used to create substrates of different viscosities [24]. Bacterial motility is also an energy-intensive process as bacteria need to have enough energy to move. So, some bacteria will only move in energy-rich environments [10]. On the other hand, bacteria will often expend the energy they have stored when the environment cannot provide sufficient energy, so that they can transport themselves to a more favourable environment [25].

Another factor influencing bacterial motility is the slime of bacteria, which consists of polysaccharides and other surface-active components, such as amino acids and peptides [26]. These components offer bacteria protection from desiccation by water retention providing a hydrated milieu within which cell appendages function and, thus, promote cell motility [17,27]. The components of the slime of bacteria also serve as cell density signals that regulate the expression of genes and, thus, coordinate cell movements $[17,28]$. Temperature is finally a factor that affects motility in most bacteria [29].

Motile cells are generally found to form flat biofilms spreading out on the exposed substratum; in contrast, immotile cells have been found to form round biofilm structures [30] with rigid walls surrounding hollow structures [31]. There are several types of surface cell motility; swarming motility, which requires flagella organelles; twitching motility, which requires type IV pili organelles; gliding motility, which requires a group of bacteria and; sliding motility, which requires a growing colony of bacteria [17]. Twitching motility is required in order cells to form mushroom-shaped biofilm structures in quiescent or low shear stress environments [32,33]. These types of surface motility enable bacteria to establish symbiotic and pathogenic associations with plants and animals [34]. Most bacterial species are motile using flagella; the structure and arrangement of these appendages are different from species to species and are related to the specific environment in which the species live. Flagella can be arranged on the cell body by single polar, multiple polar, and peritrichous or lateral configurations [35].

Swimming motility, on the other hand, is a beneficial trait for bacteria in fluid environments as it enables cell movements towards favourable environmental conditions [36,37], which are away from toxins and predators [38]. It also enables cell survival in changing environmental conditions [39]. Swimming motility is powered by rotating flagella similarly to the swarming motility on the surfaces [40]. Whereas swarming is a movement of a group of bacteria that requires many flagella, possibly because of the surface friction, swimming is an individual endeavour that requires fewer flagella. Some bacteria have distinct flagella for these two modes of motility, whereas others have only one kind of flagella for both.

It has been shown that some species of Methylobacetrium such as Methylobacterium goesingense are motile on semi-solid agar media forming small fimbriae-like structures [41]. In addition, other Methylobacterium species such as Methylobacterium marchantiae have been found to assemble a polar flagellum in liquid media [42]. In a variety of environments, such as drinking water, seawater, soil, and air, it has been shown that there are motile Methylobacterium species including Methylobacterium variabile [43], Methylobacterium salsuginis [44], Methylobacterium tarhaniae [45], and Methylobacterium iners [46]. Bacterial motility, shear stress, and quorum sensing are all known to play a significant role in triggering bacteria to form biofilms [17,47]. However, the role of these factors has not been extensively investigated for oligotrophic conditions, such as those that describe drinking water distribution systems, in which bacteria, even though they are exposed to continuous chemical stresses from the disinfection processes and high shear stresses under turbulent flow conditions, are 
found to form biofilms [48]. A number of species, such as Methylobacterium species [12], Acinetobacter calcoaceticus [4], and Mycobacterium species [12,14], have been implicated in promoting bacterial aggregation in pure or simple mixed cultures. Specifically, the Methylobacterium DSM 18358 was previously proved to be a key strain in the formation of aggregates in drinking water and, subsequently, in the formation of biofilms on available surfaces exposed to drinking water [49]. Thus, in this study the role of the motility of the Methylobacterium strain DSM 18358 in the interactions between drinking water bacteria was explored in agar plate experiments to understand if this is a significant factor for the communication between bacteria in drinking water.

\section{Materials and Methods}

The Methylobacterium strain DSM 18358 (DSMZ: Deutsche Sammlung von Mikroorganismen und Zellkulturen, Leibniz-Institute, Braunschweig, Germany) was chosen for experimental analysis in this study. The strain was cultured as described in an earlier study [49]. Two sets of experiments were conducted. In the first set of experiments, the motility of the Methylobacterium DSM 18358 was tested to see if it was affected by several factors, such as the viscosity of the substrate, the temperature, the available energy, and the type of substrate. Therefore, the motility of pure colonies of Methylobacterium was studied on agar plates under different concentrations of agar, different temperatures, and different substrate conditions to understand whether these conditions would impact the extent and direction of movement of Methylobacterium cells. In the second set of experiments, the role of Methylobacterium in the interactions between mixed drinking water bacteria was tested under the conditions that were identified as mostly favourable for the motility of Methylobacterium from the first set of experiments. To do that, both pure Methylobacterium and mixed drinking water bacterial colonies were inoculated into different agar plates.

The first set of experiments included 3 motility experiments. The total volume of medium in all of them was $30 \mathrm{~mL}$ for each agar plate. At 4 symmetric points of each agar plate, there was an injection of $5 \mu \mathrm{L}$ of the pure Methylobacterium culture [50,51], which was at the exponential phase of growth (Figure 1). To determine the exponential phase of growth of Methylobacterium, the optical density of the culture at the wavelength of $595 \mathrm{~nm}$ was monitored using the Infinite ${ }^{\circledR}$ M200 Pro automated micro-plate reader (Tecan Group Ltd., Männedorf, Switzerland) as described in an earlier study [49].

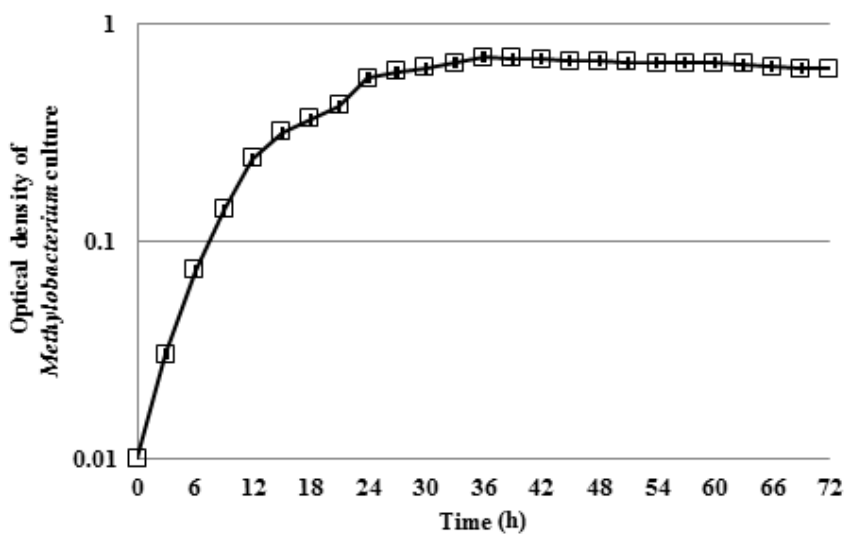

Figure 1. Growth curve of Methylobacterium culture of 1:50 dilution with optical density measured at $595 \mathrm{~nm}$ wavelength for $72 \mathrm{~h}$. The error bars represent the standard deviation of the measurements.

The 4 Methylobacterium colonies in each agar plate had an initial diameter of $2.5 \mathrm{~mm}$. All agar plates were Petri dishes with a diameter of $8.60 \mathrm{~cm}$. The distances between the pure colonies of Methylobacterium were equal to half of the radius of the Petri dish. All experiments were performed in triplicates. The maximum linear movement of Methylobacterium was firstly measured, with the starting point at the centre of injection, at a particular time and by dividing them, the maximum velocity of Methylobacterium was finally calculated. An additional measurement was to determine the diameter 
of the pure colonies of Methylobacterium at specific time periods. Finally, images of the agar plates were obtained at each of these time periods using the Molecular Imager ${ }^{\circledR} \mathrm{Gel} \mathrm{Doc}^{\mathrm{TM}}$ and the Image $\mathrm{Lab}^{\mathrm{TM}}$ Software (Bio-Rad Laboratories, Perth, UK). Motility was assessed after 12, 24, 48, and $72 \mathrm{~h}$ of incubation of the agar plates [52].

In the first motility experiment, the medium used was $3 \mathrm{~g} / \mathrm{L} \mathrm{R} 2 \mathrm{~A}$ (ThermoFisher Scientific, Loughborough, UK) [53], as this medium was previously used for the culture of Methylobacterium. Here, it was used because it is mainly composed of glucose and starch, which provide carbon for adequate energy to cells, and of amino acids and peptides, which provide favourable conditions for the bacterial slime [17]. In the same experiment, to explore the effect of viscosity, different concentrations of agar at $0.2 \%, 0.3 \%$, and $1 \%$ were tested $[52,54,55]$. To explore the effect of temperature, two different temperatures were tested. The first temperature tested was $28^{\circ} \mathrm{C}$, as this was the optimal growth temperature for the Methylobacterium strain, and the other temperature was $16^{\circ} \mathrm{C}$, which is a representative temperature for the United Kingdom for spring and summer [56].

In the second motility experiment, it was explored whether a change in the energy available to the Methylobacterium cells would affect their motility. This was achieved by testing R2A medium concentrations at $3 \mathrm{~g} / \mathrm{L}$ and $3 \mathrm{mg} / \mathrm{L}$. To ensure that neither viscosity nor temperature would limit motility, in this experiment only $0.2 \%$ agar and $28{ }^{\circ} \mathrm{C}$ temperature were used, as from the first motility experiment it was shown that higher agar concentrations $(0.3 \%$ and $1 \%)$ and lower temperature $\left(16^{\circ} \mathrm{C}\right)$ had detrimental effects on the motility of Methylobacterium.

In the third motility experiment, it was investigated whether the change of substrate and the absence of energy from the R2A medium would affect the motility of Methylobacterium. Thus, the substrate used here was drinking water that was sampled from a domestic tap in Glasgow. This is most akin to real-world conditions, admittedly with a slightly higher viscosity (again at $0.2 \%$ ), which is needed so the plates can be safely moved without disturbing any motility patterns formed. The temperature of incubation was again at $28^{\circ} \mathrm{C}$. The conditions for all 3 motility experiments are summarised in Table 1.

Table 1. Summary of conditions of the first set of experiments.

\begin{tabular}{ccccc}
\hline $\begin{array}{c}\text { First Set of } \\
\text { Experiments }\end{array}$ & Colonies & Medium & Agar (\%) & Temperature $\left({ }^{\circ} \mathrm{C}\right)$ \\
\hline 1 & $\begin{array}{c}4 \text { pure } \\
\text { Methylobacterium }\end{array}$ & $3 \mathrm{~g} / \mathrm{L} \mathrm{R} 2 \mathrm{~A}$ & $0.2,0.3,1$ & 28,16 \\
\hline 2 & $\begin{array}{c}4 \text { pure } \\
\text { Methylobacterium }\end{array}$ & $3 \mathrm{~g} / \mathrm{L} \mathrm{R} 2 \mathrm{~A}$ and $3 \mathrm{mg} / \mathrm{L} \mathrm{R} 2 \mathrm{~A}$ & 0.2 & 28 \\
\hline 3 & $\begin{array}{c}4 \text { pure } \\
\text { Methylobacterium }\end{array}$ & Drinking water & 0.2 & 28 \\
\hline
\end{tabular}

The second set of experiments included both colonies of mixed drinking water and pure Methylobacterium colonies inoculated at discrete points onto plates that comprised $30 \mathrm{~mL}$ of drinking water with $0.2 \%$ agar at $28{ }^{\circ} \mathrm{C}$. As in the first set of experiments, each inoculated colony occupied $5 \mu \mathrm{L}$ and had a surface diameter of $2.5 \mathrm{~mm}$. The distances between the colonies were the same as previously. The mixed population that was inoculated onto the plates was drawn from a drinking water culture, which was at the exponential phase of growth (Figure 2). To determine the exponential phase of growth of the drinking water culture, the optical density of the culture at the wavelength of $595 \mathrm{~nm}$ was monitored as described in an earlier study [49]. 


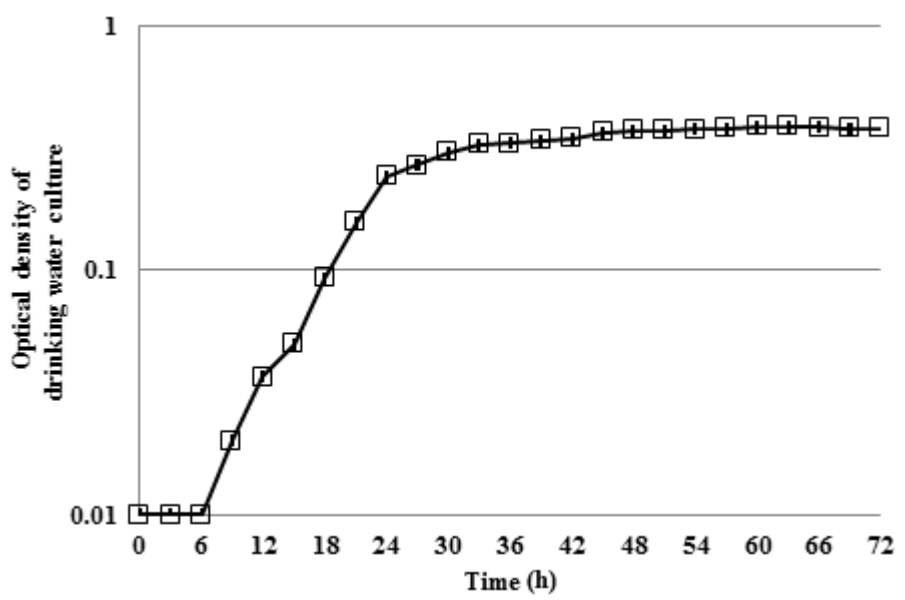

Figure 2. Growth curve of drinking water culture of 1:50 dilution with optical density measured at 595 $\mathrm{nm}$ wavelength for $72 \mathrm{~h}$. The error bars represent the standard deviation of the measurements.

The pure Methylobacterium colonies were inoculated onto the plates as described previously. Here, only images of the agar plates were obtained after 12, 24, 48, and $72 \mathrm{~h}$ of incubation as described previously. All experiments were again performed in triplicate. In the first experiment, it was explored whether the presence of Methylobacterium within mixed drinking water colonies would impact the interactions between cells. Therefore, 4 colonies of mixed drinking water bacteria were compared with 4 colonies of mixed drinking water bacteria with the Methylobacterium inoculated at $1 \%$ relative abundance. The reason to inoculate Methylobacterium in drinking water only at $1 \%$ relative abundance was that it was previously found that Methylobacterium was able to significantly enhance bacterial aggregation in drinking water even at $1 \%$ relative abundance under both stagnant and flow conditions.

In the second experiment, it was tested whether the presence of pure Methylobacterium colonies in the same plate with mixed drinking water colonies would result in different findings from those of the first experiment. Therefore, 2 colonies of mixed drinking water bacteria and 2 pure colonies of Methylobacterium in a plate were compared with 2 colonies of mixed drinking water with the Methylobacterium inoculated at 1\% relative abundance and 2 pure colonies of Methylobacterium in another plate. The conditions of these experiments are summarised in Table 2.

Table 2. Summary of conditions of the second set of experiments.

\begin{tabular}{clccc}
\hline $\begin{array}{c}\text { Second Set of } \\
\text { Experiments }\end{array}$ & \multicolumn{1}{c}{ Colonies } & Medium & Agar (\%) & Temperature $\left({ }^{\circ} \mathbf{C}\right)$ \\
\hline 1 & $\begin{array}{l}4 \text { drinking water colonies } \\
\text { versus } \\
4 \text { drinking water colonies with } \\
1 \% \text { Methylobacterium }\end{array}$ & Drinking water & 0.2 & 28 \\
& $\begin{array}{l}2 \text { drinking water colonies }+ \\
2 \text { Methylobacterium colonies } \\
\text { versus } \\
2 \text { drinking water colonies with } \\
1 \% \text { Methylobacterium }+\end{array}$ & Drinking water & 0.2 & \\
& 2 Methylobacterium colonies & & \\
\end{tabular}

\section{Results and Discussion}

\subsection{Motility of Pure Methylobacterium Colonies}

In the first motility experiment, it was found that the viscosity and the temperature had significant effects on the motility of Methylobacterium. The bacteria only moved in the lowest agar concentration 
$(0.2 \%)$ and only at $28^{\circ} \mathrm{C}$; at agar concentrations above the $0.2 \%$ and at $16{ }^{\circ} \mathrm{C}$ temperature, there was no motility observed on the plates. This is unsurprising as the drag is related to both the viscosity and the velocity, and the energy required to overcome the viscous drag force increases with viscosity. In addition, it was expected to find this result regarding the temperature, as the $16{ }^{\circ} \mathrm{C}$ is a much lower temperature than the optimum for the Methylobacterium at $28^{\circ} \mathrm{C}$. Thus, all subsequent motility experiments were conducted for the lowest viscosity environment at $28{ }^{\circ} \mathrm{C}$.

In the second motility experiment, in which the concentration of R2A was varied to ascertain the effect of different levels of energy on the motility of Methylobacterium, it was found that the motility was enhanced for the higher concentration of R2A at $3 \mathrm{~g} / \mathrm{L}$. In the third motility experiment, it was found that the absence of energy affected the motility of Methylobacterium, which was found to be further decreased when drinking water was used as the available medium.

Overall, it was shown that the motility of Methylobacterium was decreased with time with the maximum velocity of Methylobacterium cells be at the first $12 \mathrm{~h}$. The medium with the highest offered energy to cells was the one for which the highest velocity of Methylobacterium was found (Figure 3). The maximum diameter of Methylobacterium colonies was determined at the first $12 \mathrm{~h}$ for all the tested conditions. After $12 \mathrm{~h}$ of incubation, the diameter of the colonies was not changed and, thus, no further measurements were recorded (Figure 4).

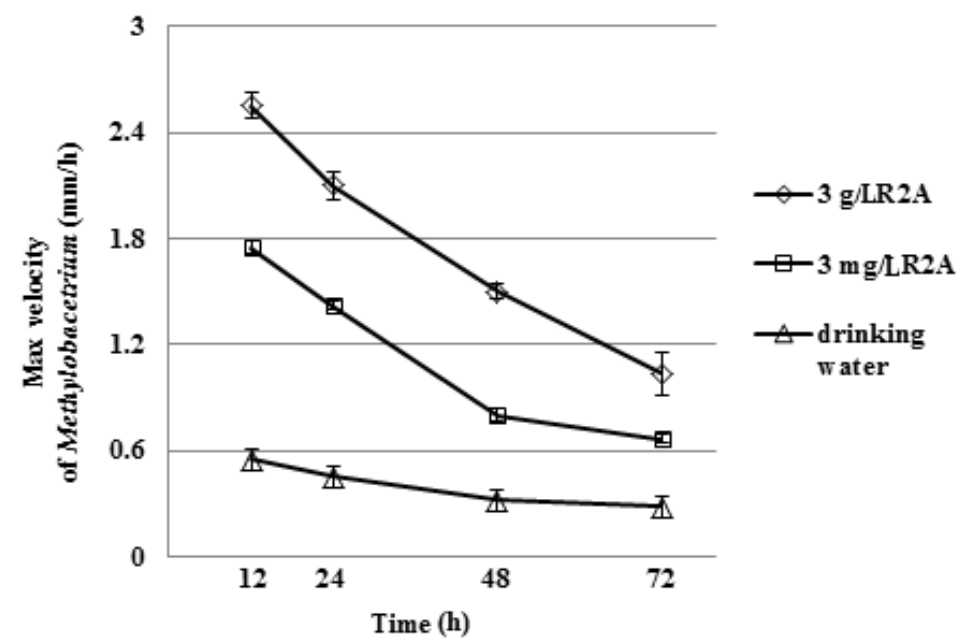

Figure 3. Motility of Methylobacterium at $0.2 \%$ agar medium after 12, 24, 48, and $72 \mathrm{~h}$ of incubation at $28^{\circ} \mathrm{C}$.

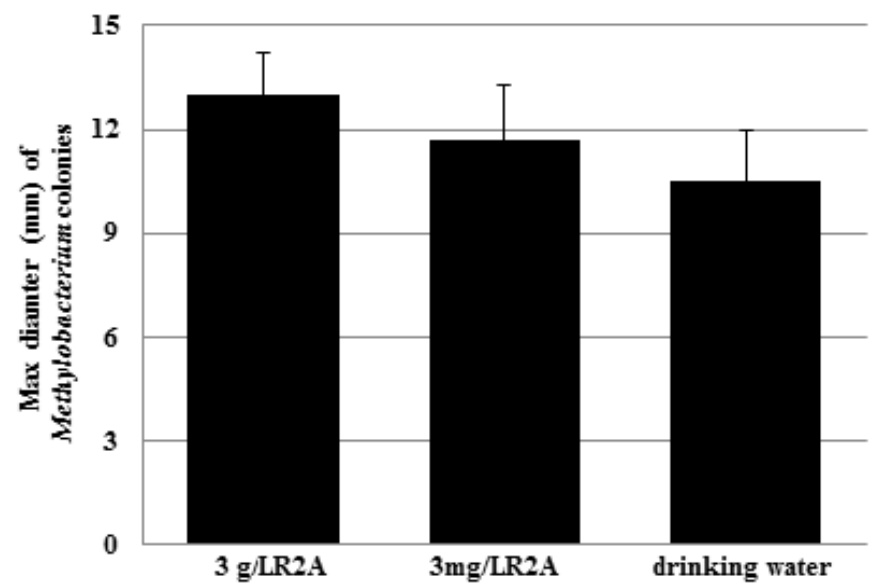

Figure 4. Maximum diameter of pure Methylobacterium colonies at $0.2 \%$ agar after $12 \mathrm{~h}$ of incubation at $28^{\circ} \mathrm{C}$. 
From the images obtained, the Methylobacterium colonies were found to have the same behaviour when R2A was the available medium (Figure 5a,b). The colonies migrated towards the centre of the dish and then moved off "en masse" towards the wall to the dish. The fact that they first moved in a coordinated manner towards the centre suggests that the organisms can sense one-another, perhaps through chemotaxis and that there is some benefit to aggregating. The fact that once congregated in the centre of the plate they moved off together rather than spreading radially suggests that once aggregated they acted in a coordinated way perhaps driven by some sort of quorum sensing. On the other hand, the behaviour of the Methylobacterium colonies in drinking water was clearly different from that in R2A medium (Figure $5 \mathrm{c}$ ). The colonies here appeared to move away from one another. This pattern shows that there was no aggregation between cells. The fact that the bacteria moved away from one another suggests that chemotaxis may well be at play, but it is chemotaxis in search of resources. Thus, the bacteria moved away from where the population was dense and resources were depleted.

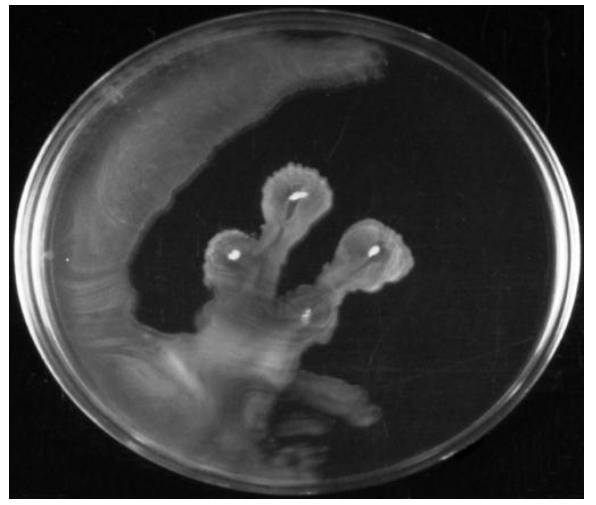

(a)

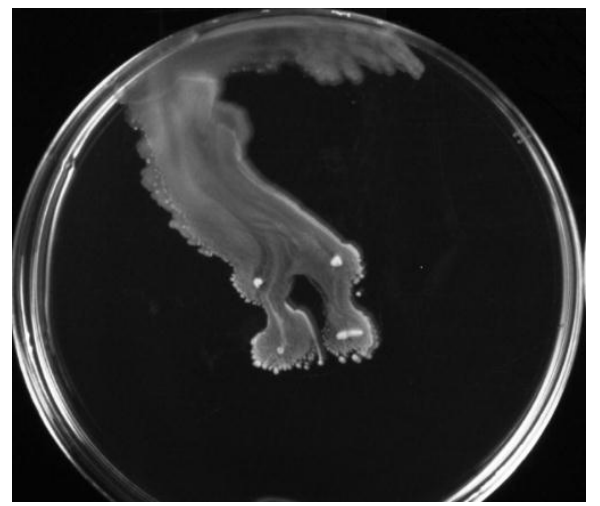

(b)

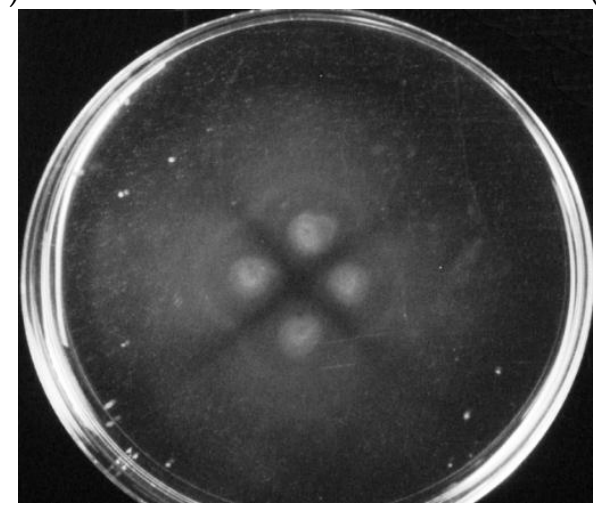

(c)

Figure 5. Motility of Methylobacterium in different substrate conditions at $0.2 \%$ agar medium after $12 \mathrm{~h}$ of incubation at $28^{\circ} \mathrm{C}$ : (a) in $3 \mathrm{~g} / \mathrm{L} \mathrm{R} 2 \mathrm{~A}$; (b) in $3 \mathrm{mg} / \mathrm{L} \mathrm{R} 2 \mathrm{~A}$; (c) in drinking water.

\subsection{Interactions of Mixed Drinking Water and Pure Methylobacterium Colonies}

From the images obtained in the first experiment, it was observed that in the mixed drinking water colonies in which Methylobacterium was inoculated at $1 \%$ relative abundance, there were more bacterial movements observed on the agar plates, and bacteria tended to communicate more with each other (Figure 6b) compared to the mixed drinking water colonies in which there was no Methylobacterium inoculated (Figure 6a). 


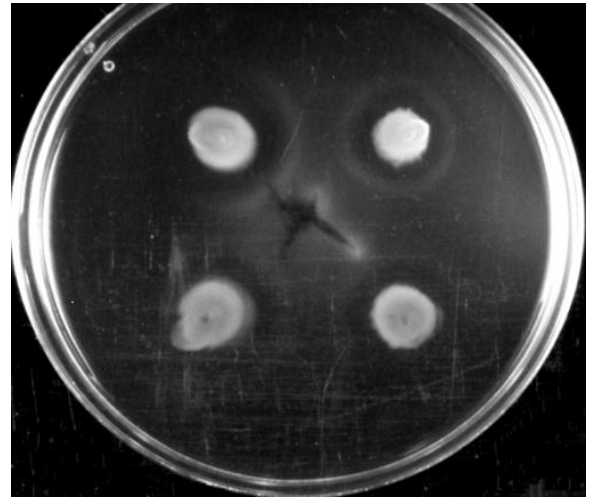

(a)

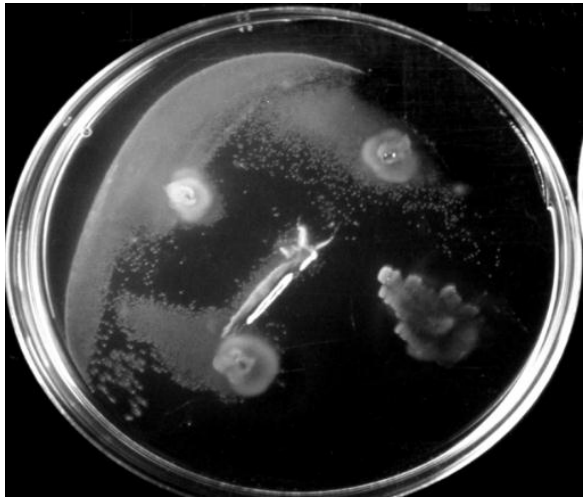

(b)

Figure 6. Interactions of mixed drinking water colonies with and without Methylobacterium addition after $12 \mathrm{~h}$ of incubation: (a) Four mixed drinking water colonies and (b) four mixed drinking water colonies with $1 \%$ Methylobacterium inoculated.

From the images obtained in the second experiment, in which there was presence of both pure colonies of Methylobacterium and mixed drinking water colonies in the same plate, it was found that the pure Methylobacterium colonies were not able to grow in the plate as the mixed drinking water colonies did (Figure 7). However, it was again obvious that in the two mixed drinking water colonies in which there was Methylobacterium inoculated at $1 \%$ relative abundance, there were more bacterial movements observed on the agar plates (Figure 7b) compared with those in which there was no addition of Methylobacterium in the two mixed drinking water colonies (Figure 7a). The most important difference of this experiment with the previous one is that here there were cell interactions between the two mixed drinking water colonies without the inoculated 1\% Methylobacterium (Figure 7a), which were not observed in the four mixed drinking water colonies, which were again without the inoculated $1 \%$ Methylobacterium in the first experiment (Figure 7a). This suggests that even the presence of pure Methylobacterium colonies in the plate triggered the communication between the mixed drinking water colonies.

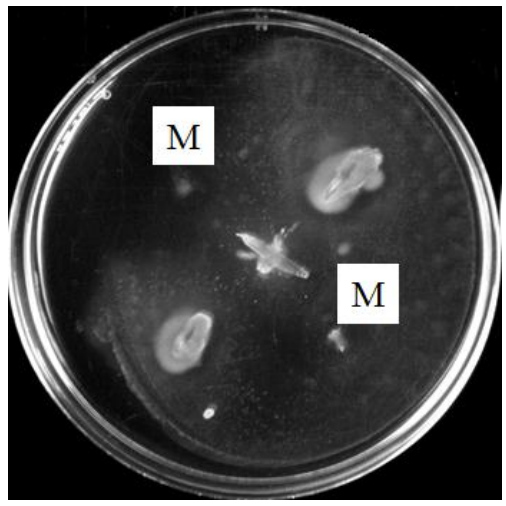

(a)

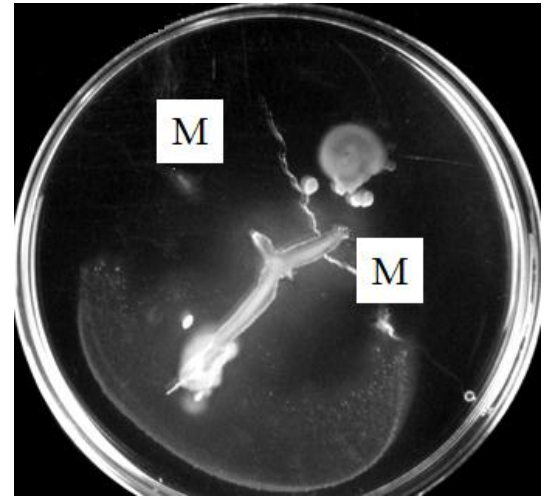

(b)

Figure 7. Interactions of mixed drinking water colonies with and without Methylobacterium, and of pure Methylobacterium colonies after $12 \mathrm{~h}$ of incubation: (a) Two mixed drinking water colonies and two pure colonies of Methylobacterium (indicated with " $\mathrm{M}^{\text {") }}$ ) and (b) two mixed drinking water colonies with 1\% Methylobacterium inoculated, and two pure colonies of Methylobacterium (indicated with " $\mathrm{M}^{\prime}$ ).

From the first set of experiments in which the Methylobacterium DSM 18358 was the only present species on the plates, it was shown that the Methylobacterium was motile only for the lowest agar concentration at $0.2 \%$ and the higher temperature tested at $28{ }^{\circ} \mathrm{C}$. This indicated the important role that the viscosity of the substrate and the temperature play in the motility of the Methylobacterium. The most 
favourable conditions for the motility of the Methylobacterium were those in which the highest energy was provided to cells. This was found in R2A medium, in which cells were communicating with each other and tending to aggregate. When the medium switched from energy sufficient conditions to drinking water, the motility of Methylobacterium was decreased and the pure colonies tended to spread away from each other in the search for nutrients.

From the second set of experiments in which the Methylobacterium was inoculated into mixed drinking water bacterial colonies at $1 \%$ relative abundance, it was found that its presence significantly enhanced the communication between drinking water bacteria even in a nutrient-poor environment like drinking water. It was also found that the presence of pure Methylobacterium colonies on the same plate with mixed drinking water colonies enhanced the ability of the drinking water bacteria to interact with each other and aggregate. The patterns observed from both sets of experiments were obvious even from the first $12 \mathrm{~h}$.

\section{Conclusions}

This work suggests that the Methylobacterium strain DSM 18358 might quorum sense by sending chemical signals to one-another and other species of drinking water bacteria. This means of communication triggered bacterial aggregation by motile bacteria depending on the energy available in the surrounding environment. The knowledge that there are key species in aggregation in drinking water whose motility might play an important role in this aggregation and, subsequently, in the initiation of biofilm formation at the inner surface of pipes could be useful in designing methods to eradicate those bacteria or, at least, reduce their concentration in the main water flow. Since the identification of key bacteria in cell aggregation in drinking water is still at an early stage, other key species in bacterial aggregation in simple mixed cultures need to be tested for their ability to form aggregates in complex mixed drinking water cultures. Considering these key species in bacterial aggregation, further research on other Methylobacterium strains, and other species, such as the Acinetobacter calcoaceticus and the Mycobacterium species, would perhaps provide a greater understanding of the role of cell motility as well as quorum sensing and shear in their ability to communicate and form aggregates with other bacteria in drinking water. Ultimately this knowledge of key species in the process of biofilm formation will allow a more nuanced approach to control biofouling.

Author Contributions: E.T. and W.T.S. conceived the experiments; E.T. designed and performed the experiments; E.T. and W.T.S. wrote the paper.

Funding: This work was supported by the University of Glasgow James Watt Scholarship and the Engineering and Physical Sciences Research Council (EP/K038885/1).

Conflicts of Interest: The authors declare no conflict of interest.

\section{References}

1. Garrett, T.R.; Bhakoo, M.; Zhang, Z. Bacterial adhesion and biofilms on surfaces. Prog. Nat. Sci. 2008, 18, 1049-1056. [CrossRef]

2. Hori, K.; Matsumoto, S. Bacterial adhesion: From mechanism to control. Biochem. Eng. J. 2010, 48, 424-434. [CrossRef]

3. Hall-Stoodley, L.; Stoodley, P. Biofilm formation and dispersal and the transmission of human pathogens. Trends Microbiol. 2005, 13, 7-10. [CrossRef] [PubMed]

4. Simões, L.C. Biofilms in Drinking Water, in Biofilms in Drinking Water: Formation and Control; Lambert Academic Publishing: Saarbrücken, Germany, 2012.

5. Boe-Hansen, R. Microbial Growth in Drinking Water Distribution Systems. Environment E Resources; Technical University of Denmark: Copenhagen, Denmark, 2001.

6. Kumarasamy, M.V.; Maharaj, P.M. The effect of biofilm growth on wall shear stress in drinking water PVC pipes. Pol. J. Environ. Stud. 2015, 24, 2479-2483. [CrossRef] 
7. Derlon, N.; Masse, A.; Escudie, R.; Bernet, N.; Paul, E. Stratification in the cohesion of biofilms grown under various environmental conditions. Water Res. 2008, 42, 2102-2110. [CrossRef] [PubMed]

8. Paul, E.; Ochoa, J.C.; Pechaud, Y.; Liu, Y.; Line, A. Effect of shear stress and growth conditions on detachment and physical properties of biofilms. Water Res. 2012, 46, 5499-5508. [CrossRef] [PubMed]

9. Fraser, G.M.; Claret, L.; Furness, R.; Gupta, S.; Hughes, C. Swarming-coupled expression of the Proteus mirabilis hpmBA haemolysin operon. Microbiology 2002, 148, 2191-2201. [CrossRef] [PubMed]

10. Mattick, J.S. Type IV pili and twitching motility. Annu. Rev. Microbiol. 2002, 56, 289-314. [CrossRef] [PubMed]

11. Macfarlane, S.; Hopkins, M.J.; Macfarlane, G.T. Toxin synthesis and mucin breakdown are related to swarming phenomenon in Clostridium septicum. Infect. Immun. 2001, 69, 1120-1126. [CrossRef] [PubMed]

12. Senesi, S.; Celandroni, F.; Salvetti, S.; Beecher, D.J.; Wong, A.C.L.; Ghelardi, E. Swarming motility in Bacillus cereus and characterization of a fliY mutant impaired in swarm cell differentiation. Microbiology 2002, 148, 1785-1794. [CrossRef] [PubMed]

13. Mireles, J.R.; Toguchi, A.; Harshey, R.M. Salmonella enterica serovar typhimurium swarming mutants with altered biofilm-forming abilities: Surfactin inhibits biofilm formation. J. Bacteriol. 2001, 183, 5848-5854. [CrossRef] [PubMed]

14. O'Toole, G.A.; Kolter, R. Flagellar and twitching motility are necessary for Pseudomonas aeruginosa biofilm development. Mol. Microbiol. 1998, 30, 295-304. [CrossRef] [PubMed]

15. Pratt, L.A.; Kolter, R. Genetic analysis of Escherichia coli biofilm formation: Roles of flagella, motility, chemotaxis and type I pili. Mol. Microbiol. 1998, 30, 285-293. [CrossRef] [PubMed]

16. Recht, J.; Kolter, R. Glycopeptidolipid acetylation affects sliding motility and biofilm formation in Mycobacterium smegmatis. J. Bacteriol. 2001, 183, 5718-5724. [CrossRef] [PubMed]

17. Harshey, R.M. Bacterial motility on a surface: Many ways to a common goal. Ann. Rev. Microbiol. 2003, 57, 249-273. [CrossRef] [PubMed]

18. Picioreanu, C.; Kreft, J.U.; Klausen, M.; Haagensen, J.A.J.; Tolker-Nielsen, T.; Molin, S. Microbial motility involvement in biofilm structure formation-A 3D modelling study. Water Sci. Technol. 2007, 55, 337. [CrossRef] [PubMed]

19. Son, K.; Brumley, D.R.; Stocker, R. Live from under the lens: Exploring microbial motility with dynamic imaging and microfluidics. Nat. Rev. Microbiol. 2015, 13, 761-775. [CrossRef] [PubMed]

20. Jefferson, K.K. What drives bacteria to produce a biofilm? FEMS Microbiol. Lett. 2004, 236, 163-173. [CrossRef] [PubMed]

21. Riedel, K.; Hentzer, M.; Geisenberger, O.; Huber, B.; Steidle, A.; Wu, H.; Hoiby, N.; Givskov, M.; Molin, S.; Eberl, L. N-acylhomoserine-lactone-mediated communication between Pseudomonas aeruginosa and Burkholderia cepacia in mixed biofilms. Microbiology 2001, 147, 3249-3262. [CrossRef] [PubMed]

22. Huber, B.; Riedel, K.; Hentzer, M.; Heydorn, A.; Gotschlich, A.; Givskov, M.; Molin, S.; Eberl, L. The cep quorum-sensing system of Burkholderia cepacia H111 controls biofilm formation and swarming motility. Microbiology 2001, 147, 2517-2528. [CrossRef] [PubMed]

23. Poonguzhali, S.; Madhaiyan, M.; Sa, T. Production of acyl-homoserine lactone quorum-sensing signals is widespread in gram-negative Methylobacterium. J. Microbiol. Biotechnol. 2007, 17, 226-233. [PubMed]

24. Mattick, J.S. Type IV pili and twitching motility. Ann. Rev. Microbiol. 2002, 56, 289-314. [CrossRef] [PubMed]

25. Martinez, A.; Torello, S.; Kolter, R. Sliding motility in mycobacteria. J. Bacteriol. 1999, 181, 7331-7338. [PubMed]

26. Matsuyama, T.; Harshey, R.M.; Matsushita, M. Self-similar colony morphogenesis by bacteria as the experimental model of fractal growth by a cell population. Fractals 1993, 1, 302-311. [CrossRef]

27. Toguchi, A.; Siano, M.; Burkart, M.; Harshey, R.M. Genetics of swarming motility in Salmonella enterica serovar typhimurium: Critical role for lipopolysaccharide. J. Bacteriol. 2000, 182, 6308-6321. [CrossRef] [PubMed]

28. Fraser, G.M.; Hughes, C. Swarming motility. Curr. Opin. Microbiol. 1999, 2, 630-635. [CrossRef]

29. Matsuyama, T.; Bhasin, A.; Harshey, R.M. Mutational analysis of flagellum-independent surface spreading of Serratia marcescens 274 on a low-agar medium. J. Bacteriol. 1995, 177, 987-991. [CrossRef] [PubMed]

30. Klausen, M.; Aaes-Jorgensen, A.; Molin, S.; Tolker-Nielsen, T. Involvement of bacterial migration in the development of complex multicellular structures in Pseudomonas aeruginosa biofilms. Mol. Microbiol. 2003, 50, 61-68. [CrossRef] [PubMed] 
31. Purevdorj, B.; Stoodley, P. Biofilm structure, behavior, and hydrodynamics. In Microbial Biofilms; ASM Press: Washington, DC, USA, 2004.

32. Hall-Stoodley, L.; Costerton, J.W.; Stoodley, P. Bacterial biofilms: From the natural environment to infectious diseases. Nat. Rev. Microbiol. 2004, 2, 95-108. [CrossRef] [PubMed]

33. Craig, L.; Pique, M.E.; Tainer, J.A. Type IV pilus structure and bacterial pathogenicity. Nat. Rev. Microbiol. 2004, 2, 363-378. [CrossRef] [PubMed]

34. Rashid, M.H.; Kornberg, A. Inorganic polyphosphate is needed for swimming, swarming, and twitching motilities of Pseudomonas aeruginosa. Proc. Natl. Acad. Sci. USA 2000, 97, 4885-4890. [CrossRef] [PubMed]

35. Soutourina, O.A.; Semenova, E.A.; Parfenova, V.V.; Danchin, A.; Bertin, P. Control of bacterial motility by environmental factors in polarly flagellated and peritrichous bacteria isolated from Lake Baikal. Appl. Environ. Microbiol. 2001, 67, 3852-3859. [CrossRef] [PubMed]

36. Dennis, P.G.; Seymour, J.; Kumbun, K.; Tyson, G.W. Diverse populations of lake water bacteria exhibit chemotaxis towards inorganic nutrients. ISME J. 2013, 7, 1661-1664. [CrossRef] [PubMed]

37. Stocker, R.; Seymour, J.R.; Samadani, A.; Hunt, D.E.; Polz, M.F. Rapid chemotactic response enables marine bacteria to exploit ephemeral microscale nutrient patches. Proc. Natl. Acad. Sci. USA 2008, 105, 4209-4214. [CrossRef] [PubMed]

38. Samad, T.; Billings, N.; Birjiniuk, A.; Crouzier, T.; Doyle, P.S.; Ribbeck, K. Swimming bacteria promote dispersal of non-motile staphylococcal species. ISME J. 2017, 11, 1933-1937. [CrossRef] [PubMed]

39. Galajda, P.; Keymer, J.; Chaikin, P.; Austin, R. A wall of funnels concentrates swimming bacteria. J. Bacteriol. 2007, 189, 8704-8707. [CrossRef] [PubMed]

40. Kearns, D.B. A field guide to bacterial swarming motility. Nat. Rev. Microbiol. 2010, 8, 634-644. [CrossRef] [PubMed]

41. Schauer, S.; Kutschera, U. A novel growth-promoting microbe, Methylobacterium funariae sp. nov., isolated from the leaf surface of a common moss. Plant Signal. Behav. 2011, 6, 510-515. [CrossRef] [PubMed]

42. Doerges, L.; Kutschera, U. Assembly and loss of the polar flagellum in plant-associated methylobacteria. Naturwissenschaften 2014, 101, 339-346. [CrossRef] [PubMed]

43. Gallego, V.; Garcia, M.T.; Ventosa, A. Methylobacterium variabile sp. nov., a methylotrophic bacterium isolated from an aquatic environment. Int. J. Syst. Evol. Microbiol. 2005, 55, 1429-1433. [CrossRef] [PubMed]

44. Wang, X.; Sahr, F.; Xue, T.; Sun, B. Methylobacterium salsuginis sp. nov., isolated from seawater. Int. J. Syst. Evol. Microbiol. 2007, 57, 1699-1703. [CrossRef] [PubMed]

45. Veyisoglu, A.; Camas, M.; Tatar, D.; Guven, K.; Sazaki, A.; Sahin, N. Methylobacterium tarhaniae sp. nov., isolated from arid soil. Int. J. Syst. Evol. Microbiol. 2013, 63, 2823-2828. [CrossRef] [PubMed]

46. Weon, H.Y.; Kim, B.Y.; Joa, J.H.; Son, J.A.; Song, M.H.; Kwon, S.W.; Go, S.J.; Yoon, S.H. Methylobacterium iners sp. nov. and Methylobacterium aerolatum sp. nov., isolated from air samples in Korea. Int. J. Syst. Evol. Microbiol. 2008, 58, 93-96. [CrossRef] [PubMed]

47. Liu, S.; Gunawan, C.; Barraud, N.; Rice, S.A.; Harry, E.J.; Amal, R. Understanding, monitoring, and controlling biofilm growth in drinking water distribution systems. Environ. Sci. Technol. 2016, 50, 8954-8976. [CrossRef] [PubMed]

48. Tsagkari, E.; Sloan, W.T. Turbulence accelerates the growth of drinking water biofilms. Bioprocess Biosyst. Eng. 2018, 41, 757-770. [CrossRef] [PubMed]

49. Tsagkari, E.; Keating, C.; Couto, J.M.; Sloan, W.T. A keystone Methylobacterium strain in biofilm formation in drinking water. Water 2017, 9, 778. [CrossRef]

50. Hauwaerts, D.; Alexandre, G.; Das, S.K.; Vanderleyden, J.; Zhulin, I.B. A major chemotaxis gene cluster in Azospirillum brasilense and relationships between chemotaxis operons in alpha-proteobacteria. FEMS Microbiol. Lett. 2002, 208, 61-67. [PubMed]

51. Rasmussen, L.; White, E.L.; Pathak, A.; Ayala, J.C.; Wang, H.X.; Wu, J.H.; Benitez, J.A.; Silva, A.J. A high-throughput screening assay for inhibitors of bacterial motility identifies a novel inhibitor of the $\mathrm{Na}+$-driven flagellar motor and virulence gene expression in Vibrio cholerae. Antimicrob. Agents Chemother. 2011, 55, 4134-4143. [CrossRef] [PubMed]

52. Simões, L.C.; Simões, M.; Vieira, M.J. Biofilm interactions between distinct bacterial genera isolated from drinking water. Appl. Environ. Microbiol. 2007, 73, 6192-6200. [CrossRef] [PubMed]

53. Reasoner, D.J.; Geldreich, E.E. A New Medium for the Enumeration and Subculture of Bacteria from Potable Water. Appl. Environ. Microbiol. 1985, 49, 1-7. [PubMed] 
54. Wolfe, A.J.; Berg, H.C. Migration of bacteria in semisolid agar. Proc. Natl. Acad. Sci. USA 1989, 86, 6973-6977. [CrossRef] [PubMed]

55. Ben-Jacob, E.; Schohet, O.; Tenenbaum, A.; Cohen, I.; Czirók, A.; Vicsek, T. Generic modelling of cooperative growth patterns in bacterial colonies. Nature 1994, 368, 46-49. [CrossRef] [PubMed]

56. Douterelo, I.; Sharpe, R.L.; Boxall, J.B. Influence of hydraulic regimes on bacterial community structure and composition in an experimental drinking water distribution system. Water Res. 2013, 47, 503-516. [CrossRef] [PubMed]

(c)

(C) 2018 by the authors. Licensee MDPI, Basel, Switzerland. This article is an open access article distributed under the terms and conditions of the Creative Commons Attribution (CC BY) license (http://creativecommons.org/licenses/by/4.0/). 